\title{
Outcomes of service encounter quality in a
}

\section{business-to-business context}

\author{
Chanaka Jayawardhena \\ The Business School \\ Loughborough University \\ Loughborough \\ LE11 3TU \\ UK
}

Tel: + 44 (0) 1509228831

Email: c.jayawardhena@lboro.ac.uk

Anne L Souchon,

The Business School

Loughborough University

Loughborough

LE11 3TU

UK

Tel: + 44 (0) 1509228832

Email: a.1.souchon@lboro.ac.uk

Andrew M Farrell,

The Business School

Loughborough University

Loughborough

LE11 3TU

UK

Tel: + 44 (0) 1509228842

Email: a.m.farrell@lboro.ac.uk

Kate Glanville

Endeavour Capital Ltd

Level Five, Wakefield House

90 The Terrace, PO Box 10811

Wellington

New Zealand

Tel: + 64 (0) 44995140

Email: kate.glanville@ecap.co.nz 


\section{Brief Biographical Sketches:}

Chanaka Jayawardhena is a Lecturer in Marketing at Loughborough University, UK. His research interests include service quality and consumer behavior. Previous publications have appeared in the Journal of Marketing Management, Journal of General Management, Journal of Internet Research, among others.

Anne L Souchon is a Reader in Marketing and Director of Postgraduate Research Programs at Loughborough University, UK. Her research interests include export marketing, information acquisition and use, and services marketing. Previous publications have appeared in the Journal of Business Research, the Journal of International Marketing, the Journal of Strategic Marketing, International Marketing Review, among others.

Andrew M Farrell is a Research Associate in Marketing at Loughborough University, UK. His research interests include service quality, leadership, and organizational behavior. Previous publications have appeared in the Journal of Marketing Management.

Kate Glanville currently works as the Executive Assistant for Endeavour Capital Ltd, in Wellington, New Zealand. Her research interests include services marketing and service quality. 


\begin{abstract}
Service encounter quality is an area of growing interest to researchers and managers alike, yet little is known about the effects of face-to-face service encounter quality within a business-tobusiness setting. In this paper, a psychometrically sound measure of such service encounter quality is proposed, and consequences of this construct are empirically assessed. Both a literature review and a dyadic in-depth interview approach were used to develop a conceptual framework and a pool of items to capture service encounter quality. A mail survey of customers was undertaken, and a response rate of $36 \%$ was obtained. Data analysis was conducted via confirmatory factor analysis and structural equation modeling. Findings reveal a four-factor structure of service encounter quality, encompassing professionalism, civility, friendliness and competence dimensions. Service encounter quality was found to be directly related to customer satisfaction and service quality perceptions, and indirectly to loyalty. The importance of these findings for practitioners and for future research on service encounter quality is discussed.
\end{abstract}

Keywords: service encounter quality, customer satisfaction, service quality, loyalty, business-tobusiness, professional services. 


\section{Introduction}

The service sector has seen dramatic growth over the years, to the extent that its contribution to global GNP exceeds that of all other sectors combined (The World Bank 2004). However, a number of dynamic factors affect the service industry including government regulation, social changes, business trends, advances in technology, and internationalization (Hoffman et al 1995; Rust \& Oliver, 1994). Within deregulated and competitive markets, differentiation strategies, including delivering quality services (Parasuraman et al 1988; Cronin \& Taylor 1992) are a primary concern of services marketers (Fisher 1991).

Within the service quality domain, the importance of customers' perceptions of service encounters is increasingly recognized (Mill 1986; Namasivayam \& Hinkin 2003). In the words of Bitner et al (1994, p. 95), "from the customer's point of view, the most immediate evidence of service quality occurs in the service encounter or the 'moment of truth' when the customer interacts with the firm. Thus, one central goal in the pursuit of 'zero defects' in service is to work toward $100 \%$ flawless performance in service encounters". Consequently, these encounters can become an integral part of the image that the customer has of the firm and, in turn, will play an influential role in determining the success of the firm (Bitner 1990; Bitner et al 1990). As Hartline et al (2003, p. 43) point out, customers "base their evaluations on their perceptions of the service encounter", due to the inter-personal nature of services.

Bitran \& Lojo (1993) explain that service encounters are not random events; they can be treated systematically. Scope is thus high for management control over the success or failure of specific 
service encounters. Accordingly, "the quality of the service encounter has been recognized as a key strategic competitive weapon" (Mattila \& Enz 2002, p. 269).

Previous work on service encounters has almost exclusively focused upon retail consumers (Kong \& Mayo 1993; Westbrook \& Peterson 1998). Indeed, service encounter quality in a business-to-business context tends to be both overlooked at the managerial level (Bitran \& Lojo 1993 ) and under-researched academically (Brown et al 1994; Chumpitaz \& Paparoidamis 2004; Durvasula et al 1999; Gounaris 2005; Hartline \& Jones 1996). This is surprising given the importance of contact personnel and the social/interpersonal aspects of the encounter in businessto-business services (Paulin et al 2000). As explained by Drennan \& McColl-Kennedy (2003), professional services tend to be "people-directed".

The business-to-business context has numerous unique characteristics that warrant special attention. First, business-to-business situations are usually typified by a small number of customers, each contributing significant value to the overall business; the importance of each service encounter is thus more pronounced (McNamara 1972). Second, it is also the case that business-to-business service encounters are often more frequent than in the case of business-toconsumer transactions (Hardy 1978). In fact, given the advance of technology, professional services firms report increased use of communication equipment (e.g., cellular phones) for business use (Hooks \& Higgs 2002), thus facilitating personal interactions. Third, in most business-to-business exchanges, a service encounter is not the fulfillment of a single effort but an event in a broader endeavor to build and sustain a long-term relationship (Jammernegg \& Kischka 2005; Miciak \& Desmarais 2001). Fourth, "both academics and practitioners recognize that business-to-business relationships are characterized by closer and deeper interfaces than 
consumer relationships" (Mehta \& Durvasula 1998, p. 40). Finally, an examination of the service encounter is crucial as service provider employees must be more flexible and innovative because of the potential non-routine elements in their jobs (Dubinsky et al 1986).

Despite the importance of service encounter quality to business-to-business firms (Paulin et al 2000), to the authors' best knowledge, no measure of this construct exists. Thus, there is a call for the development of psychometrically sound measures of service encounter quality in a businessto-business sector. Furthermore, consequences of service encounter quality should be empirically examined in order to develop clear managerial guidelines for the development of optimal service encounter quality strategies in business-to-business (Parasuraman 1998).

The objectives of this study are twofold: a) to develop a psychometrically sound measure of faceto-face, interpersonal service encounter quality in the context of business-to-business exchanges; and b) to empirically examine the consequences of face-to-face, interpersonal service encounter quality, again within the context of business-to-business exchanges.

This study intends to contribute to our growing understanding of customers' perceptions of service encounters. From the industrial practitioner's point of view, measurement of service encounter quality is critical for a number of reasons. First, if service encounter quality can be captured, the instrument could be used as a benchmarking tool for service providers in comparing their service provision against that of competitors. According to Rust \& Oliver (1994) delivering a superior service offers an opportunity to achieve competitive differentiation. Secondly, improvements in the quality of service encounters can only be made if the current level of service encounter quality is known. This knowledge can be obtained through use of a reliable and valid 
measure. Thirdly, effective measurement of service encounter quality can be useful in the allocation of resources and in segmentation of customers, since assessment scores of generic service constructs, such as service quality, can be used as an effective tool for segmentation (Parasuraman et al 1988). Finally, understanding consequences of service encounter quality has important managerial implications. According to Paulin et al (2000), successful interaction between professional service provider and customer is likely to result in enhanced customer satisfaction and loyalty. In turn, the benefits of satisfaction and loyalty are well documented (Chebat \& Slusarczyk 2005; Heskett et al 1997). By understanding the interrelationships between these constructs, management may be able to contribute to increased firm performance (Chumpitaz \& Paparoidamis 2004; Heskett et al 1994). These reasons in combination make the findings of this research both timely and relevant.

This paper is arranged as follows. The next section provides a background for the constructs of interest. This is followed by a presentation of conceptual development. The methodology used is then described, followed by the study's results. Discussion of findings and strategic implications for the business-to-business service sector are then provided. Limitations and future research avenues conclude the paper.

\section{Literature and theoretical background}

Person-to-person interactions are an essential element in the marketing of services (Czepiel 1990; Crosby et al 1990; Surprenant \& Solomon 1987). Customers' perceptions of face-to-face interaction with service employees have traditionally been considered one of the most important 
determinants for customer satisfaction and firm loyalty (Berry 1983; Oliver et al 1997; Liljander \& Mattsson 2002; Winsted 2000). Similarly, service quality has been found to be related to customer loyalty, arguably the bedrock of any business (Caruana 2002). The following sections thus provide a brief background of the service encounter, service quality, customer satisfaction and loyalty constructs.

\section{Service Encounters}

To date, the literature on service encounters has mostly focused on the consumer sector (Paulin et al 2000). Nevertheless, and in terms of conceptual definitions, characteristics of consumer services appear to be applicable to the business-to-business sector (Cooper \& Jackson 1988), though this is not true of their operationalizations (Durvasula et al 1999).

The literature offers broad definitions of service encounters. For example, Shostack's (1985) definition encompasses elements beyond the interpersonal element of a service encounter, including physical surroundings and self-service technology. On the other hand, more narrow definitions of service encounters also exist, focusing on the interpersonal nature of the encounter. For instance, Surprenant \& Solomon (1987) define the service encounter as a dyadic interaction between the customer and service provider. This definition draws on their earlier work suggesting that service encounters are role performances (Czepiel et al 1985) in which both customers and service providers have roles to enact. During the service encounter, or 'moment-of-truth', the formation of customer perceptions is often more largely based upon the emotional and intangible content of the encounter than on surroundings (Lemmink \& Mattsson 2002; Stauss \& Mang 1999). Indeed, "traditionally, service encounters have been characterized as low tech, high face- 
to-face contact" (Drennan \& McColl-Kennedy 2003, p. 296). In a business-to-business setting, Paulin et al (2000) explain that contact personnel and social/interpersonal aspects of the encounter play a much greater role than technology in forming quality perceptions. Even in the context of high-tech service organizations, it has been argued that "several reasons make the ability of the customer contact person crucial when delivering complex services" (Mattsson 2000, p. 24). Thus, for the purposes of this paper, Surprenant \& Solomon's (1987) dyadic conceptualization of service encounters as an inter-personal construct is adopted.

There are a number of distinguishing characteristics of service encounters (Czepiel 1990). First, service encounters are purposeful. The contact takes place to achieve a specific goal. Second, service encounters are limited in scope, and restricted by the nature and content of the service to be delivered. Third, the roles played by the service provider and the customer in the service encounter are generally well-defined and understood by both parties. This suggests that service encounters are shaped by individual behaviors and the nature and quality of customer and employee interactions (Bitner 1990; Bitner et al 1994; Heskett et al 1994). Zeithaml \& Bitner (2003) refer to the strategic framework within which these interactions take place as the 'services triangle'. They show how the three interlinked groups (i.e., customers, company and company employees) work together to develop, promote and deliver services.

Recent work examining service encounters has attempted to formulate conceptualizations of the number of dimensions contained within the construct (e.g., Keillor et al 2004; Raajpoot 2004; Winsted 2000). Chandon et al (1997) developed a dyadic assessment of service encounters encompassing competence of staff, listening behaviors of staff, dedication of staff, and effectiveness of staff. Winsted (2000) developed a three-dimensional measure to assess service 
encounter evaluation which encompassed concern, civility and congeniality. Raajpoot (2004) developed a measure of service encounter quality encompassing seven-dimensions including tangibility, reliability, assurance, sincerity, personalization, formality, and responsiveness. Finally, Keillor et al (2004) sought to examine service encounters in a multi-country investigation, and measured service encounter evaluation as physical goods quality, service quality, the servicescape, and behavioral intentions.

What is apparent from this brief review of the literature, however, is that all of the prior work was conducted in a business-to-consumer context, and only three of the studies (Parasuraman et al 1985; Raajpoot 2004; Winsted 2000) sought input from employees as well as customers with regards to what constitutes a high quality service encounter.

\section{Service Quality}

Parasuraman et al (1985) initially identified ten dimensions of service quality. These ten dimensions were then empirically reduced to five (SERVQUAL), namely: tangibles, reliability, responsiveness, assurance and empathy (Parasuraman et al 1988). In a business-to-business context, Durvasula et al (1999, p. 140) further found that "SERVQUAL's five dimensions could be reduced to a smaller number", and claim that "other research is needed to determine if the SERQUAL scale can be reduced to a more parsimonious structure".

Early work (Grönroos 1982; 1984; Lewis \& Booms 1983) conceptualized service quality as a disconfirmation process. However, subsequent authors noted conceptual, theoretical and measurement problems with the disconfirmation model (Brown et al 1993; Teas 1993; 1994). 
The topic of perceptions-minus-expectations or perceptions-only measures of service quality dominated the services marketing literature during the 1990s (Babakus \& Boller 1992; Cronin \& Taylor 1992; 1994; Parasuraman et al 1994; Teas 1993; 1994; Zeithaml et al 1996). More recently, evidence has been pointing towards perceptions-only measures as being more psychometrically robust (Brady et al 2002; Cronin \& Taylor 1992; Dabholkar et al 2000). As a result, it is now more common to see perceptions-only subsets of the SERVQUAL battery being applied to measure service quality (e.g., Cronin et al 2000; Keillor et al 2004; Hartline \& Ferrell 1996; Laroche et al 2004; Witkowski \& Wolfinbarger 2002). This is also true for service quality in a business-to-business context (Durvasula et al 1999).

\section{Customer Satisfaction}

Customer satisfaction is generally conceptualized as an attitudinal judgment about purchase (Yi 1990). It can pertain to an individual transaction or to a series of purchases over time (Fournier \& Mick 1999), although much of past research on customer satisfaction has taken the transactionspecific perspective (Anderson \& Fornell 1994). Thus, while service quality is an overall construct of perceptions about a firm's service provision, satisfaction is based on an individual service encounter (c.f., Boulding et al 1993). As stated by Voss et al (2004, p. 213), "service quality is a distinct construct from customer satisfaction”. Similarly, service encounter quality and customer satisfaction are also distinct. The former pertains to cognitive judgments on the service provider's behavior during purchase (e.g., Wilsted 2000). On the other hand, customer satisfaction is a emotive post-consumption evaluation of the service performance (e.g., Caruana 2002). 
In a consumer context, service encounters have been linked to customer satisfaction; Winsted (2000) found that service encounter dimensions (concern, civility, and congeniality) were positively related to satisfaction. More recently, Chumpitaz \& Paparoidamis (2004) called for more empirical investigation of the relationships between business-to-business service quality and satisfaction.

\section{Loyalty}

Early views on loyalty focused on repeat purchase behavior. For example, Brown (1952) classified loyalty into four categories based on the purchase patterns of customers: undivided loyalty; divided loyalty; unstable loyalty; and no loyalty. Other researchers of this period (e.g., Kuehn 1962) measured loyalty by the probability of product repurchase. Day (1969) and Jacoby \& Chestnut (1978) have suggested that such behavioral definitions are insufficient because they do not distinguish between true loyalty and spurious loyalty that may result, for example, from a lack of available alternatives for the consumer. In response to these criticisms, researchers have proposed measuring loyalty by means of an attitudinal dimension in addition to the behavioral dimension. In this context, Engel \& Blackwell (1982) asserted that loyalty is the preferential attitudinal and/or behavioral response towards one or more brands in a product category expressed over a period of time by a customer. What is clear from this brief review of early research on customer loyalty is the pronounced focus on products and brands, rather than services. While more recent work has started to address this imbalance (Bloemer et al 1998), loyalty to service organizations remains under-explored (Caruana 2002). For the purposes of this paper, we seek to explore differing facets of loyalty, namely loyalty to the employee and loyalty to the organization (c.f., Fullerton 2003). 


\section{Conceptualization}

A body of literature exists to support the conceptual notion that the quality of customer-employee interactions plays a critical role in the development of service quality perceptions (Bitran \& Lojo 1993; Danaher \& Mattsson 1994; Stauss \& Mang 1999). As explained by Farrell et al (2001, p. 577), “service quality represents a customer's assessment of the overall level of service offered by an organization, and this assessment is often based upon perceptions formulated during service encounters”. Czepiel (1990) also places the specific short-term service encounter at the heart of customers' general long-term perceptions of service quality. It appears from this that positive perceptions of service encounter quality may lead to normative expectations of the overall quality of the service. Service quality is considered to be a holistic judgment of quality, and the quality of individual service encounters should contribute towards this judgment. Thus, we expect that:

H1: $\quad$ Service encounter quality perceptions will be positively related to overall service quality evaluations.

In accepting the classical conceptualization of customer satisfaction as relating to a post-purchase emotive judgment of an individual service encounter (Caruana 2002), one can argue that customer satisfaction will play a mediating role between service encounter quality (a cognitive evaluation of the encounter as it occurs) and overall service quality (based upon the customer's experience with the firm over time). Indeed, "the satisfaction process often has a strong social 
dimension" (Fournier \& Mick 1999, p. 15, emphasis in the original), indicating that it may be related to the quality of the interaction between service provider and customer. We therefore anticipate the following:

H2: $\quad$ Service encounter quality perceptions will be positively related to customer satisfaction.

The literature on service quality and customer satisfaction demonstrates the interrelationships between the constructs (e.g., Voss et al 2004). In general, the literature treats these constructs as static, at least for estimation purposes. Expectations play a very important role in both constructs. Expectations can be standardized along two main themes, predictive expectations and normative expectations (Boulding et al 1993). Work carried out by Prakash (1984) suggests that customer satisfaction literature relies on expectations as a prediction of future events. Normative expectations of future events are operationalized as either desired or ideal expectations (Prakash 1984; Swan \& Trawick 1981). This is the standard typically used in the service quality literature (Parasuraman et al 1988). Yet, there is a clear difference between overall quality as opposed to satisfaction/dissatisfaction with a specific incident (Boulding et al 1993). Paulin et al (2000, p. 454) depict the chronological chain of reactions to a successful business-to-business service encounter: "being very satisfied, rating service quality highly, intending to continue purchasing the services, desiring to purchase new services and willing to recommend the firm to others". In addition, recent work by Tian-Cole et al (2005) demonstrates that the quality of an individual service experience predicted satisfaction, which in turn predicts overall service quality. Hence, we expect to see a positive relationship between transaction-specific satisfaction and overall service quality evaluation, as follows: 
H3: Customer satisfaction will be positively related to overall service quality perceptions.

Research on consumer loyalty in a services marketing context reports a high positive correlation between satisfaction, quality and loyalty (Anderson et al 1994; Bitner 1990; Bolton \& Drew 1991; Cronin et al 2000; Dabholkar et al 2000; Farrell et al 2001; Zeithaml et al 1996). Boulding et al (1993) explain that the greater the perceptions of overall service quality, the more likely the customers will engage in behaviors beneficial to the firm, such as loyalty to the organization. Indeed, service quality encompassing an assessment of the general services provided by an organization rather than an individual service transaction (Boulding et al 1993), it seems likely that it will be related to loyalty to the organization. When a customer uses service quality as their frame of reference, they consider the whole organization, including the employees, who are seen to represent it (Bitner et al 1994). In a series of studies, Parasuraman et al $(1988 ; 1991 ; 1994)$ found a positive and significant relationship between customers' perceptions of service quality and their willingness to recommend the company. Overall service quality has a significant effect upon customers' intention to repeat purchase (Cronin et al 2000), and on general customer loyalty (c.f., Too et al 2001). Equally, equity theory suggests that providing superior service quality leads to repurchase intentions (Kelley \& Davis 1994), in a business-to-business setting as well (Bendapudi \& Leone 2002). Thus it is hypothesized that:

H4: Overall service quality will be positively related to loyalty to the organization. 
Marketers have often emphasized the need to provide customer satisfaction to achieve loyalty (e.g., Szymanski \& Henard 2001). Customer satisfaction is often seen as derived from individual transactions (Host \& Knie-Andersen 2004), where the employee is the frame of reference.

Further, business customers' relationships with the employee who serves them can be stronger than the relationship with the organization (Bendapudi \& Leone 2002). As a result, customer satisfaction is likely to be directly linked to loyalty to an individual service provider, rather than to the organization as a whole. Indeed, as explained by McAlexander et al (2003), the way in which loyalty develops is more dynamic and complex than commonly modeled, and may include important personal and social aspects. Fullerton (2003, p. 335) further discusses the emotional attachment which customers can develop towards their "partner in a consumption relationship". He equates affective commitment to friendship, rapport, and trust towards the service provider. Given the importance of personal contacts in business-to-business organizations (Bendapudi \& Leone 2002), we expect that:

H5: Customer satisfaction will be positively related to loyalty to the employee.

The development of customer loyalty can also be an evolutionary process driven by experience (McAlexander et al 2003). Morgan \& Hunt (1994) found that transactional variables such as quality and trust ultimately lead to customer retention. As a result of this, Fullerton (2003) suggested that commitment to the individual service provider may be an important driver of organizational loyalty in services industries. In his experimental study of undergraduate students, he found that an affective commitment to a service provider was indeed a powerful determinant to customer retention. Affective commitment is characterized by an emotional bond of friendship with the individual service provider and leads to the highest levels of overall loyalty (Curasi \& 
Kennedy 2002). This is likely to be the case in a business-to-business context as well where vendor firms implement relationship marketing through key contact personnel in a bid to secure repeat business (Bendapudi \& Leone 2002). Thus, the following is hypothesized:

H6: Loyalty to the employee will be positively related to loyalty to the organization.

The model shown in Figure 1 postulates that service encounter quality and customer satisfaction influence service quality, which in turn, contributes to loyalty to the organization. It further shows a relationship between customer satisfaction and loyalty to the individual service provider.

\section{Place Figure 1 Here}

\section{Methodology}

The study was conducted in a single industry in order to overcome contextual bias (see Hartline \& Jones 1996). The first objective was to develop a measure of service encounter quality, applicable to a business-to-business context. Scale development procedures mirror the work of earlier researchers (Churchill 1979; Parasuraman et al 1988). The process of developing an instrument in this paradigm involves: (i) identifying the domain of the construct; (ii) generating a sample of items; (iii) collecting data; (iv) purifying measures; (v) assessing reliability, dimensionality and validity; and (vi) developing norms. Secondly, the study sought to examine the consequences of service encounter quality, namely overall service quality, satisfaction, 
loyalty to the employee, and loyalty to the organization. Again, traditional methods involving structural equation modeling were used.

\section{Sample and Procedures}

The project was financially supported by a private safety inspection organization in New Zealand. A database consisting of 50 service providers and 778 customers was obtained from this organization. Each service provider had between 10 and 20 customers. Service provider-customer dyads were researched in a qualitative in-depth study, the purpose of which was to assist in the development of the conceptual framework and a pool of items for service encounter quality measurement. Nine in-depth interviews of safety inspection customers and providers were conducted. Three initial interviews were conducted with general customers to identify the important dimensions they associate with service encounter quality. A further six interviews (three safety inspection providers and three safety inspection customers) were conducted. Each interview was analyzed according to the sequence of steps advocated by Miles \& Huberman (1984) and followed by Bitner et al (1990). From this analysis we generated a pool of 41 items measuring perceptions of service encounter quality.

Both the literature review and the results of the preliminary study were used to develop a formal structured instrument (see section below on measures used). The questionnaire was pre-tested using peer reviews and protocols of two service providers and three customers. Questionnaires were mailed out to customers and follow-up cards and follow-up letters were subsequently sent to non-respondents after one and two weeks respectively. In order to ensure the results were a true reflection of what occurs within the business-to-business context, anonymity and confidentiality 
of respondents and their organization was assured and outlined in a cover letter sent with the questionnaire.

A total of 329 questionnaires were returned, including 281 usable and 47 non-usable replies, indicating a response rate of $36 \%$. A non-response bias analysis was conducted utilizing a timetrend extrapolation test, and t-tests comparing early and late respondents (Armstrong \& Overton 1977). The t-tests were found to be non-significant at a 5\% level, indicating the probable lack of non-response bias (see Appendix A).

Respondents were found to be mostly male ( $94 \%$ of the total sample), aged 46 on average, with an undergraduate degree (30\% of the sample). The organizations they work for command an average annual turnover of NZ\$71,820,423 (though $50 \%$ of the sample reported a turnover of NZ\$4,000,000 or less). On average, firms had been established for 33 years. Performance measures included subjective self-reported 7-point scales (from 1=poor to 7=outstanding) capturing profitability, sales growth, profit growth, competitiveness, fulfillment of objectives, and market share. Means and standard deviations were, respectively, 4.5/1.4 (for profitability), 4.4/1.3 (for sales growth), 4.3/1.4 (for profit growth), 5.4/1.2 (for competitiveness), 5.3/1.2 (for fulfillment of objectives), and 4.2/1.3 (for market share).

\section{Measures Used}

Questionnaire items for the service encounter quality scale were derived from both the literature and the qualitative study. Service quality (e.g., Parasuraman et al 1988), customer satisfaction (e.g., Oliver 1997), loyalty (e.g., Mowday et al 1979) were derived from the literature review. 
Where necessary, minor modifications were made to suit a business-to-business service context (Durvasula et al 1999).

In line with arguments proposed by Cronin \& Taylor (1992), and our previous discussion of the service quality literature, we adopted perceptions-only as opposed to a perceptions-minusexpectations measures of service encounter quality and service quality.

It should be noted that the perceptions-specific items of SERVQUAL scale developed by Parasuraman et al (1988) can be applied to a business-to-business context (e.g., Mehta \& Durvasula 1998). However, the factor configuration of the scale is open to change, and likely to yield a smaller number of factor than the traditional five, namely tangibles, responsiveness, assurance, empathy and reliability (e.g., Durvasula et al 1999).

In general, 7-point Likert-type scales were employed. This was due to most scales being directly applied in their pre-existing form (e.g. Parasuraman et al 1988). However, in two instances, 9point Likert-type scales were used, since the protocols identified limited variation in responses to some of the items. The 9-point scale used was unbalanced to reduce the number of negative (i.e., "disagree") options, and allow for more variation in the "agree" side of the Likert-type scale (Cadogan et al 2001). Appendix B illustrates the questionnaire items.

\section{Results}

The analysis was run on a consistent sample of 234 customers. The first data analytical stage consisted of an exploratory principal axis factoring of all constructs of interest. This resulted in 
the first deletions of poorly performing items from the scales based on weak or cross-loadings. Confirmatory factor analysis (CFA) was then run using LISREL 8.3. The final CFA fit indices were all found to be above recommended thresholds (see first row in Table 1). The fit indices chosen in Table 1 were used because a combination of such indices has been shown to achieve a good balance between Type I and Type II error rates when assessing model fit (Hu \& Bentler 1999). Appendices B and C contain the items retained in the final model, and the correlation/covariance matrices of items and higher order variables, respectively.

\section{Place Table 1 Here}

After exploratory and confirmatory factor analysis, perceptions of service encounter quality yielded four dimensions: professionalism, civility, friendliness and competence. Four dimensions of service quality (Parasuraman et al 1988) emerged (tangibles, assurance, empathy, and reliability) and customer satisfaction, loyalty to the organization, and loyalty to the employee were unidimensional. Following Homburg \& Pflesser (2000), we calculated composite reliabilities and average variance extracted for scales composed of more than two items, and coefficient alpha for two-item scales. This resulted in values above the minimum recommended thresholds of 0.7 for composite reliability and coefficient alpha (Nunnally \& Bernstein 1994), and 0.5 for average variance extracted (Fornell \& Larcker 1981) for all scales (see Table 2). Discriminant validity between all constructs was assessed by examining correlations between all pairs of multi-item scales. The correlations were first set at unity, and then freed. In every case, significant decreases in $\chi^{2}$ were observed on freeing the correlation between the scales, demonstrating evidence for discriminant validity. Thus, the measures used for this study were 
both reliable and valid. In terms of testing for common method bias, results of the Harman test using principal axis factoring revealed a 5-factor structure with no general factor present (the first factor accounted for only $18.6 \%$ of the variance).

\section{Place Table 2 Here}

In testing for the support of the hypotheses, a structural model was run using LISREL 8.3. The fit indices are in the "Model" row of Table 1. The results are presented diagrammatically in Figure 2. All t-values are significant at the $1 \%$ level, except in the relationship between perceptions of service encounter quality and perceptions of service quality. In this case, the t-value is 2.224 , which falls just below the critical value of 2.32 for a $1 \%$ significance.

\section{Place Figure 2 Here}

Figure 2 reveals that all hypotheses were supported. Specifically, service encounter quality is positively associated with both service quality and customer satisfaction, confirming the importance of personal customer-employee interactions in developing positive emotive judgments and longer-term perceptions towards the firm. Customer satisfaction was found to be positively related to service quality and loyalty to the employee. Thus, the emotive aspect of postpurchase evaluation plays a part in enhancing long-term perceptions of the overall organization as well as the commitment to purchasing regularly to the individual with whom the original interaction occurred. In turn, service quality has a positive association with loyalty to the organization. This is an important finding which indicates that the quality of staff-customer 
interactions does not simply enhance the customer's feelings of loyalty to the individual, which could actually be a dangerous situation particularly in the context of high staff turnover (c.f., Hooks \& Higgs 2002). Rather, satisfactory staff-customer interactions also indirectly influence the extent to which customers feel loyalty towards the organization as a whole. Finally, it was found that loyalty to the employee is also positively related to loyalty to the organization, thus justifying any strategy aiming to increase loyalty to staff, in a business-to-business context.

\section{Discussion of Managerial Implications}

\section{Service Encounter Quality Measurement}

From a theoretical point of view, the paper fills a research gap in that it represents, to the authors' best knowledge, the first attempt at measuring service encounter quality in a business-to-business context. Our research reveals that service encounter quality as perceived by customers in a business-to-business context is defined by four dimensions: professionalism, civility, friendliness, and competence. This operationalization differentiates from the traditional perspective of service quality in that it pertains specifically to the inter-personal aspects of customer-supplier interactions, the most critical side of business-to-business exchange (Paulin et al 2000).

The scale also has a variety of potential managerial applications, in that it can facilitate a business-to-business service encounter quality program through a multitude of methods. First, the dimensional format of the instrument allows the organization to assess its level of service encounter quality in detail, as well as holistically. Thus, the relative importance of the four dimensions of service encounter quality can be determined and used to direct employees to focus 
on the 'more salient' elements. Second, it can be used to periodically track customer perceptions of service encounter quality of an organization relative to that of its competitors. This may be useful in assessing overall company performance compared with that of the competition. By extension it can used to gauge effectiveness of changes in service delivery. Third, the instrument can be used to identify dissatisfied customers, so that service recovery can be attempted. Fourth, it can be used to track the level of service provided by individual employees of the service provider organization. An evaluation of employee characteristics in different clusters may reveal attributes that are critical for ensuring high service encounter quality. This can facilitate the appraisal of the service performance of individuals and terms for evaluation, recognition, and rewards. Finally, the scale can be used to categorize an organization's customers into several service encounter quality segments, on the basis of their individual instrument scores. These segments can then be compared and contrasted on characteristics such as firm size, location, business volume, etc. Such a process may allow the service provider to apply the concept of customer orientation by targeting optimal segments more effectively. It may be argued that assessments of service encounter quality would change with time and the nature of the interaction. Hence the service encounter quality construct is unlikely to be stable and therefore caution should be employed if using it as a valid segmentation criterion. However, services by their very nature are intangible, perishable, inseparable and heterogeneous. Therefore, it is true that with time and the nature of the interaction, assessments of service encounter quality could change. It can also be argued that with the ingredients of time and nature of interaction, any related construct of the service, such as service quality, customer satisfaction, etc. could change. However, it is well-established that assessment scores of service constructs, such as service quality, can be used as an effective tool for segmentation (Parasuraman et al 1988). In this research, we have demonstrated that there is a significant relationship between service encounter 
quality and service quality and therefore it is likely that the service encounter quality scale can likewise be used to categorize an organization's customers into segments.

\section{Consequence of Service Encounter Quality}

The theoretical framework tested also raises several challenging implications. Academically, the results lend further strength to established models. Namely, the impact of service quality and satisfaction upon customer loyalty demonstrates the theoretical soundness of the service profit chain (Heskett et al 1994; Heskett et al 1997). Prior work has supported the service profit chain in banking (Kamakura et al 2002) and our work lends some strength to its cross-industry and crosscontextual applicability by examining the service profit chain at work in the context of businessto-business services.

In terms of managerial implications, firms may be able to contribute to the achievement of organizational objectives through careful and creative management of the service encounter. In addition to ascertaining the dimensions of service encounter quality, the research indicates that service encounters have an influence on customer satisfaction, service quality and loyalty to both employees and organizations (the service profit chain). The research suggests that customers perceive service providing employees as the vital link capable of enhancing customer satisfaction and service quality. The advantages accruing to organizations as a result of improved service quality and customer satisfaction are well-documented (Cronin et al 2000; Heskett et al 1997). Perhaps most importantly it is empirically shown that enhanced customer satisfaction leads to improved forms of customer loyalty. Business-to-business customers appear to demonstrate their loyalty on two levels: first, loyalty towards the employee at an individual level, and second, 
towards the organization as a whole. This is a finding of significant value to business organizations since enhanced loyalty has been recognized as a key strategic competitive weapon.

\section{Limitations and suggestions for future research}

When evaluating the results of research it is always pertinent to consider the limitations inherent in the work. Firstly, a longitudinal study could assess causality between constructs in a way the current study cannot; however, the number of respondents in this study and the complicated nature of having to match respondents' answers over a long period of time negated the use of longitudinal work in this instance.

Secondly, the research was conducted in a single industry. While this has the obvious benefits of controlling for cross-industry variation, we must stress that caution be employed if attempting to generalize these results to other industries. As explained by Drennan \& McColl-Kennedy (2003, p. 298), "businesses in the service industry cannot and must not be regarded as the same". In this context, for service firms characterized by high technology service provision, the importance and repercussions of the personal service encounter may be reduced. Further research into the consequences of service encounter quality in a business-to-business context should thus include the direct replication of the presented structural model in other service industries, possibly hightech ones, employing longitudinal data collection if possible.

Third, the research is of a limited dyadic nature, in that whilst employees and customers were canvassed for measure development, only customers were surveyed for quantitative analytical 
purposes. Future research work should look to assess both employees' and customers' perceptions of service encounter quality.

Fourth, we acknowledge the blossoming stream of literature examining the impact of self-service technology (SST) in service encounter evaluations (e.g., Bitner et al 2000; Curran et al 2003; Meuter et al 2005), and suggest that the future researcher in the field of service encounters includes dimensions related to technology in their instrument.

Finally, a study on antecedents to service encounter quality in a business-to-business context is warranted in order to ascertain the relative impact of organizational, environmental, and customer-specific factors on the extent to which business customers perceive service encounter quality to be high. Of particular relevance is the idea of the consumer as a co-producer of the service (Vargo \& Lusch 2004).

Notwithstanding these limitations, the area of service encounter quality in a business-to-business context remains significantly under researched and subsequent work in this important area of the literature is certainly both timely and warranted. 


\section{References}

Anderson, E. W. \& Fornell, C. (1994), A Customer Satisfaction Research Prospectus. In R. T. Rust \& R. L. Oliver (Eds.), Service Quality: New Directions in Theory and Practice. Thousand Oaks, CA: Sage Publications, 241-268.

Anderson, E. W., Fornell, C., \& Lehmann, D. (1994, July), Customer Satisfaction, Market Share and Profitability: Findings from Sweden. Journal of Marketing, 58, 53-66.

Armstrong, J. S. \& Overton, T. S. (1977, August), Estimating Nonresponse Bias in Mail Surveys. Journal of Marketing Research, 14, 396-402.

Babakus, E. \& Boller, G.W. (1992), An Empirical Assessment of the SERVQUAL Scale. Journal of Business Research, 24 (3), 253-268.

Bagozzi, R. P., Baumgartner, H., \& Yi, Y. (1992), Appraisal Processes in the Enactment of Intentions to Use Coupons. Psychology and Marketing, 9 (6), 469-486.

Bendapudi, N. \& Leone, R. P. (2002), Managing Business-to-Business Customer Relationships Following Key Contact Employee Turnover in a Vendor Firm. Journal of Marketing, 66 (2), 83-102.

Berry, L. L. (1983), Relationship Marketing. In L. L. Berry, G. L. Shostack, \& G. D. Upah (Eds.), Emerging Perspectives in Services Marketing (pp. 25-28). Chicago, IL: American Marketing Association.

Bitner, M. J. (1990), Evaluating Service Encounters: The Effects of Physical Surrounding on Employee Responses. Journal of Marketing, 54 (2), 69-82.

Bitner, M. J., Booms, B. H., \& Tetrault, M. S. (1990, January), The Service Encounter: Diagnosing Favorable and Unfavorable Incidents. Journal of Marketing, 54, 71-84. 
Bitner, M. J., Booms, B. H., \& Mohr, L. A. (1994, October), Critical Service Encounters: The Employees’ Viewpoint. Journal of Marketing, 58, 95-106.

Bitner, M. J., Brown, S. W., \& Meuter, M. L. (2000), Technology Infusion in Service Encounters. Journal of the Academy of Marketing Science, 28 (1), 138-149.

Bitran, G. \& Lojo, M. (1993), A Framework for Analyzing the Quality of the Customer Interface. European Management Journal, 11 (4), 385-396.

Bloemer, J., de Ruyter, K., \& Peeters, P. (1998), Investigating Drivers of Bank Loyalty: The Complex Relationship Between Image, Service Quality and Satisfaction. International Journal of Bank Marketing, 16 (7), 276-286.

Bolton, R. N. \& Drew, J. H. (1991, January), A Longitudinal Analysis of the Impact of Service Changes on Customer Attitudes. Journal of Marketing, 55, 1-9.

Boulding, W., Kalra, A., Staelin, R., \& Zeithaml, V. A. (1993, February), A Dynamic Process Model of Service Quality: From Expectations to Behavioral Intentions. Journal of Marketing Research, 30, 7-27.

Brady, M. K., Cronin Jr., J. J., \& Brand, R. R. (2002), Performance-only Measurement of Service Quality: A Replication and Extension. Journal of Business Research, 55 (1), 17-31.

Brady, M. K. \& Robertson, C. J. (2001), Searching for a Consensus on the Antecedent Role of Service Quality and Satisfaction: An Exploratory Cross-National Study. Journal of Business Research, 51 (1), 53-60.

Brown, G. H. (1952, 9 June), Brand Loyalty - Fact or Fiction? Advertising Age, 23, 53-55.

Brown, T. J., Churchill, G. A., \& Peter, J. P. (1993). Improving the Measurement of Service Quality. Journal of Retailing, 69 (1), 127-139.

Brown, S. W., Fisk, R. P., \& Bitner, M. J. (1994), The Development and Emergence of Services Marketing Thought. International Journal of Service Industry Management, 5 (1), 21-48. 
Cadogan, J. W., Paul, N. J., Salminen, R. T., Puumalainen, K. and Sundqvist, S. (2001), Key Antecedents to "Export” Market-Oriented Behaviors: A Cross-National Empirical Examination. International Journal of Research in Marketing, 18 (3), 261-282.

Caruana, A. (2002), Service Loyalty: The Effects of Service Quality and the Mediating role of Customer Satisfaction. European Journal of Marketing, 36 (7/8), 811-828.

Chandon, J-L., Leo, P-Y., \& Philippe, J. (1997), Service Encounter Dimensions - A Dyadic Perspective: Measuring the Dimensions of Service Encounters as Perceived by Customers and Personnel. International Journal of Service Industry Management, 8 (1), 65-86.

Chebat, J. \& Slusarczyk, W. (2005), How Emotions Mediate the Effects of Perceived Justice on Loyalty in Service Recovery Situations: An Empirical Study. Journal of Business Research, 58 (5), 664-673.

Choi, K-S, Cho, W-H, Lee, S., Lee, H., \& Kim, C. (2004), The Relationships Among Quality, Value, Satisfaction and Behavioral Intention in Health Care Provider Choice: A South Korean Study. Journal of Business Research, 57 (8), 913-921.

Chumpitaz, R. \& Paparoidamis, N. G. (2004), Service Quality and Marketing Performance in Business-to-Business Markets: Exploring the Mediating Role of Client Satisfaction. Managing Service Quality, 14 (2/3), 235-248.

Churchill, G. A. (1979, February), A Paradigm for Developing Better Measures of Marketing Constructs. Journal of Marketing Research, 16, 64-73.

Churchill, G. A. \& Iacobucci, D. (2002, Fall), Marketing Research Methodological Foundations ( $8^{\text {th }} E d$.), Chicago, IL: Dryden Press.

Cooper, P. D. \& Jackson, R. W. (1988), Applying a Service Marketing Orientation to the Industrial Services Sector. Journal of Services Marketing, 2, 66-70. 
Cronin Jr., J. J. \& Taylor, S. A. (1992, July), Measuring Service Quality - A Re-Examination and Extension. Journal of Marketing, 56, 55-68.

Cronin Jr., J. J \& Taylor, S. A. (1994, January), SERVPERF Versus SERVQUAL: Reconciling Performance-Based and Perceptions-Minus-Expectations Measurement of Service Quality. Journal of Marketing, 58, 125-131.

Cronin Jr., J. J., Brady, M. K., \& Hult, G. T. (2000), Assessing the Effects of Quality, Value, and Customer Satisfaction on Consumer Behavioral Intentions in Service Environments. Journal of Retailing, 76 (2), 193-218.

Crosby, L. A., Evans, K. R., \& Cowles, D. (1990, July), Relationship Quality in Services Selling: An Interpersonal Influence Perspective. Journal of Marketing, 54, 68-81.

Curasi, C. F. \& Kennedy, K. N. (2002), From Prisoners to Apostles: A Typology of Repeat Buyers and Loyal Customers in Service Businesses. Journal of Services Marketing, 16 (4), 322-342.

Curran, J. M., Meuter, M. L., \& Suprenant, C. F. (2003), Intentions to Use Self-Service Technologies: A Confluence of Multiple Attitudes. Journal of Service Research, 5 (3), 209-224.

Czepiel, J. A. (1990), Service Encounters and Service Relationships: Implications for Research. Journal of Business Research, 20 (1), 13-21.

Czepiel, J., Solomon, M., \& Surprenant, C. (1985), The Service Encounter, Lexington, MA: Lexington Books.

Dabholkar, P. A., Shepherd, C. D., \& Thorpe, D. I. (2000), A Comprehensive Framework for Service Quality: An Investigation for Critical Conceptual and Measurement Issues Through a Longitudinal Study. Journal of Retailing, 76 (2), 139-173. 
Danaher, P. J. \& Mattsson, J. (1994), Cumulative Encounter Satisfaction in the Hotel Conference Process. International Journal of Service Industry Management, 5 (4), 69-80.

Day, G. S. (1969, September), A Two-Dimensional Concept of Brand Loyalty. Journal of Marketing Research, 9, 29-36.

Drennan, J. \& McColl-Kennedy, J. R. (2003), The Relationship between Internet Use and Perceived Performance in Retail and Professional Service Firms. Journal of Services Marketing, 17 (2/3), 295-312.

Dubinsky, A. J., Howell, R. D., Ingram, T. N., \& Bellenger, D. N. (1986, October), Salesforce Socialization. Journal of Marketing, 50, 192-207.

Durvasula, S., Lysonski, S., \& Mehta, S. C. (1999), Testing the SERVQUAL Scale in the Business-to-Business Sector: The Case of Ocean Freight Shipping Service. Journal of Services Marketing, 13 (2), 132-148.

Engel, J. F. \& Blackwell, R. D. (1982), Consumer Behavior, New York: The Dryden Press.

Farrell, A. M., Souchon, A. L., \& Durden, G. R. (2001), A Conceptualisation of Service Encounters: Employees' Service Behaviours and Customers' Perceptions of Service Quality. Journal of Marketing Management, 17 (5/6), 577-594.

Fisher, R. J. (1991), Durable Differentiation Strategies for Services. Journal of Services Marketing, 5 (1), 19-28.

Fornell, C. \& Larcker, D. F. (1981, February), Evaluating Structural Equation Models with Unobservable Variables and Measurement Error. Journal of Marketing Research, 18, 3950.

Fournier, S. \& Mick, D. G. (1999, October), Rediscovering Satisfaction. Journal of Marketing, 63, 5-24. 
Fullerton, G. (2003), When does Commitment lead to Loyalty? Journal of Services Research, 5 (4), 333-345.

González, E. A., Fraiz Brea, J. A., \& Castro, A. M. (2005), An Investigation of the Relationship Between Service Quality, Satisfaction and Behavioural Intentions: The Case of Health Spas in Spain, in G. Troilo (Ed.) Proceedings of the $34^{\text {th }}$ European Marketing Academy Conference (EMAC), 24-27 May, Milan, Italy.

Gounaris, S. P. (2005), Trust and Commitment Influences on Customer Retention: Insights from Business-to-Business Services. Journal of Business Research, 58 (2), 126-140.

Gronroos, C. (1982), A Service Quality Model and Its Management Implications, Research Report. Workshop on Research into the Management of Services, London, UK: European Institute for Advanced Studies in Management (EIASM).

Gronroos, C. (1984), A Service Quality Model and its Marketing Implications. European Journal of Marketing, 18 (4), 36-44.

Hardy, L.W. (1978), The Sales Force: Structures and Organization. European Journal of Marketing, 12 (6), 381-393.

Hartline, M. D. \& Ferrell, O. C. (1996, October), The Management of Customer-Contact Service Employees: An Empirical Investigation. Journal of Marketing, 60 (4), pp. 52-70.

Hartline, M. D. \& Jones, K. C. (1996), Employee Performance Cues in a Hotel Service Environment: Influence on Perceived Service Quality, Value, and Word-of-Mouth Intentions. Journal of Business Research, 35 (3), 207-215.

Hartline, M. D., Woolridge, B. R., \& Jones, K. C. (2003), Guest Perceptions of Hotel Quality: Determining which Employee Groups Count Most. Cornell Hotel and Administration Quarterly, 44 (1), 43-53. 
Heskett, J. L., Jones, T. O., Loveman, G. W., Sasser Jr., W. E., \& Schlesinger, L. A. (1994), Putting the Service-Profit Chain to Work. Harvard Business Review, March-April, 164174.

Heskett, J. L., Sasser Jr., W. E., \& Schlesinger, L. A. (1997), The Service Profit Chain: How Leading Companies Link Profit and Growth to Loyalty, Satisfaction, and Value, New York: Free Press.

Hoffman, K. D., Kelley, S. W., \& Rotalsky, H. M. (1995), Tracking Service Failures and Employee Recovery Efforts. Journal of Services Marketing, 9 (2), 49-62.

Homburg, C. \& Pflesser, C. (2000), A Multiple-Layer Model of Market-Oriented Organizational Culture: Measurement Issues and Performance Outcomes. Journal of Marketing Research, 37 (4), 449-462.

Hooks, K. L. \& Higgs, J. L. (2002), Workplace Environment in a Professional Services Firm. Behavioral Research in Accounting, 14, 105-128.

Host, V. \& Knie-Andersen, M. (2004), Modeling Customer Satisfaction in Mortgage Credit Companies. International Journal of Bank Marketing, 22 (1), 26-39.

Hu, L-T. \& Bentler, P. M. (1999), Cutoff Criteria for Fit Indices in Covariance Structure Analysis: Conventional Criteria Versus New Alternatives. Structural Equation Modeling: A Multidisciplinary Journal, 6 (1), 1-55.

Jacoby, J. \& Chestnut, R. W. (1978), Brand Loyalty: Measurement and Management. New York: John Wiley and Sons.

Jammernegg, W. \& Kischka, P. (2005), Dynamic Customer-Oriented Improvement of Supply Networks. European Journal of Operational Research, 167 (2), 413-426.

Kamakura, W. A., Mittal, V., de Rosa, F., \& Mazzon, J. A. (2002), Assessing the Service-Profit Chain. Marketing Science, 21 (3), 294-317. 
Keillor, B. D., Hult, G. T., \& Kandemir, D. (2004), A Study of the Service Encounter in Eight Countries. Journal of International Marketing, 12 (1), 9-35.

Kelley, S. W. \& Davis, M. A. (1994), Antecedents to Customer Expectations for Service Recovery. Journal of Academy of Marketing Science, 22 (1), 52-61.

Kong, R. \& Mayo, M. C. (1993), Measuring Service Quality in the Business-to-Business Context. Journal of Business \& Industrial Marketing, 8 (2), 5-15.

Kuehn, A. (1962, March-April), Consumer Brand Choice as a Learning Process. Journal of Advertising Research, 2, 10-17.

Laroche, M., Ueltschy, L. C., Abe, S., Cleveland, M., \& Yannopoulos, P. (2004), Service Quality Perceptions and Customer Satisfaction: Evaluating the Role of Culture. Journal of International Marketing, 12 (3), 58-85.

Lemmink, J. \& Mattsson, J. (2002), Employee Behavior, Feelings of Warmth and Customer Perception in Service Encounters. International Journal of Retail and Distribution Management, 30 (1), 18-34.

Lewis, R. C. \& Booms, B. H. (1983), The Marketing Aspects of Service Quality. In L. L. Berry, G. L. Shostack \& G. D. Upah (Eds.), Emerging Perspectives in Services Marketing (pp. 99-107). Chicago, IL: American Marketing Association.

Liljander, V. \& Mattsson, J. (2002, October), Impact of Customer Preconsumption Mood on the Evaluation of Employee Behavior in Service Encounters. Psychology and Marketing, 19, $837-847$.

Mattila, A. S., \& Enz, C. A. (2002), The Role of Emotions in Service Encounters. Journal of Service Research, 4 (4), 268-278.

Mattsson, J. (2000), Learning how to Manage Technology in Service Internationalisation. Service Industries Journal, 22 (1), 22-40. 
McAlexander, J. H., Kim, S. K., \& Roberts, S. D. (2003), Loyalty: The Influences of Satisfaction and Brand Community Integration. Journal of Marketing Theory and Practice, 11 (4), 112.

McNamara, C. P. (1972, January), The Present Status of the Marketing Concept. Journal of Marketing, 36, 50-62.

Mehta, S. C., \& Durvasula, S. (1998), Relationships between SERVQUAL Dimensions and Organizational Performance in the Case of Business-to-Business Service. Journal of Business and Industrial Marketing, 13 (1), 40-55.

Meuter, M. L., Bitner, M. J., Ostrom, A. L., \& Brown, S. W. (2005, April), Choosing Among Alternative Service Delivery Modes: An Investigation of Customer Trial of Self-Service Technologies. Journal of Marketing, 69, 61-83.

Meuter, M. L., Ostrom, A. L., Bitner, M. J., \& Roundtree, R. I. (2003), The Influence of Technology Anxiety on Consumer Use and Experiences with Self-Service Technologies. Journal of Business Research, 56 (11), 899-906.

Meuter, M. L., Ostrom, A. L., Roundtree, R. I., \& Bitner, M. J. (2000, July), Self-Service Technologies: Understanding Customer Satisfaction with Technology-Based Service Encounters. Journal of Marketing, 64, 50-64.

Miciak, A. \& Desmarais, M. (2001), Benchmarking Service Quality Performance at Business-toBusiness and Business-to-Consumer Call Centers. Journal of Business and Industrial Marketing, 16 (5), 340-354.

Miles, M. B. \& Huberman, A. M. (1984), Qualitative Data Analysis: A Sourcebook of New Methods. London: Sage.

Mill, R. C. (1986), Managing the Service Encounter. Cornell Hotel and Restaurant Administrative Quarterly, 26 (4), 39-46. 
Morgan, R. M. \& Hunt, S. D. (1994), The Commitment-Trust Theory of Relationship Marketing. Journal of Marketing, 58 (3), 20-38.

Mowday, R. T., Steers, R. M., \& Porter, L. W. (1979), The Measurement of Organizational Commitment. Journal of Vocational Behavior, 14, 224-247.

Namasivayam, K. \& Hinkin, T. R. (2003), The Customer's Role in the Service Encounter: The Effects of Control and Fairness. Cornell Hotel and Restaurant Administration Quarterly, 44 (3), 26-34.

Nunnally, J. C. \& Bernstein, I. H. (1994), Psychometric Theory (3 ${ }^{\text {rd }}$ Ed.). New York: McGrawHill.

Oliver, R. L. (1997), Satisfaction: A Behavioral Perspective on the Consumer. New York: McGraw Hill.

Oliver, R. L., Rust, R. T., \& Varki, S. (1997), Customer Delight: Foundations, Findings, and Managerial Insight. Journal of Retailing, 73 (3), 311-336.

Parasuraman, A. (1998), Customer Service in Business-to-Business Markets: An Agenda for Research. Journal of Business \& Industrial Marketing, 13 (4/5), 309-321.

Parasuraman, A., Zeithaml, V. A., \& Berry, L. L. (1985, Fall), A Conceptual Model of Service Quality and its Implications for Future Research. Journal of Marketing, 49, 41-50.

Parasuraman, A., Zeithaml, V. A., \& Berry, L. L. (1988), SERVQUAL: A Multiple-Item Scale for Measuring Consumer Perceptions of Service Quality. Journal of Retailing, 64 (1), 1240.

Parasuraman, A., Zeithaml, V. A., \& Berry, L. L. (1991), Refinement and Reassessment of the SERVQUAL Scale. Journal of Retailing, 67 (4), 420-450. 
Parasuraman, A., Zeithaml, V. A., \& Berry, L. L. (1994, January), Reassessment of Expectations as a Comparison Standard in Measuring Service Quality: Implications for Further Research. Journal of Marketing, 58, 114-124.

Paulin, M., Ferguson, R. J., \& Payaud, M. (2000), Business Effectiveness and Professional Service Personnel - Relational or Transactional Managers? European Journal of Marketing, 34 (3/4), 453-469.

Prakash, V. (1984, Fall), Validity and Reliability of the Confirmation of Expectations Paradigm as a Determinant of Consumer Satisfaction. Journal of the Academy of Marketing Science, 12, 63-76.

Raajpoot, N. (2004), Reconceptualizing Service Encounter Quality in a Non-Western Context. Journal of Service Research, 7 (2), 181-201.

Rust, R. T. \& Oliver, R. L. (1994), Service Quality: New Directions in Theory and Practice. London: Sage.

Schellhase, R., Hardock, P., \& Ohlwein, M. (1999), Customer Satisfaction in Business-toBusiness Marketing: The Case of Retail Organizations and Their Suppliers. Journal of Business \& Industrial Marketing, 14 (5/6), 416-432.

Shostack, G. L. (1985), Planning the Service Encounter. In J. A. Czepiel, M. R. Soloman, \& C. F. Suprenant (Eds.), The Service Encounter (pp. 243-254). Lexicon, MA: Lexicon Books.

Stauss, B. \& Mang, P. (1999), 'Culture Shocks' in Inter-Cultural Service Encounters? Journal of Services Marketing, 13 (4/5), 329-349.

Surprenant, C. F. \& Solomon, M. R. (1987, April), Predictability and Personalization in the Service Encounter. Journal of Marketing, 51, 73-80.

Swan, J. E. \& Trawick, F. I. (1981, Fall), Disconfirmation of Expectations and Satisfaction with a Retail Service. Journal of Retailing, 57, 49-67. 
Szymanski, D. M. \& Henard, D. H. (2001), Customer Satisfaction: A Meta-Analysis of the Empirical Evidence. Journal of the Academy of Marketing Science, 29 (1), 16-35.

Teas, R. K. (1993, October), Expectations, Performance Evaluation, and Consumers' Perceptions of Quality. Journal of Marketing, 57, 18-34.

Teas, R. K. (1994, January), Expectations as a Comparison Standard in Measuring Service Quality: An Assessment of a Reassessment. Journal of Marketing, 58, 132-139.

The World Bank (2004), The Growth of the Service Sector. http://www.worldbank.org/depweb/english/beyond/beyondco/beg_09.pdf [Accessed 13/06/04].

Tian-Cole, S., Crompton, J. L., \& Willson, V. L. (2002), An Empirical Investigation of the Relationships Between Service Quality, Satisfaction and Behavioral Intentions among Visitors to a Wildlife Refuge. Journal of Leisure Research, 34 (1), 1-24.

Too, L. H. Y., Souchon, A. L., \& Thirkell, P. C. (2001), Relationship Marketing and Customer Loyalty in a Retail Setting: A Dyadic Exploration. Journal of Marketing Management, 17 $(3 / 4), 287-319$.

Vargo, S. L., \& Lusch, R. F. (2004), Evolving to a New Dominant Logic for Marketing. Journal of Marketing, 68 (1), 1-17.

Voss, C. A., Roth, A. V., Rosenzweig, E. D., Blackmon, K. \& Chase, R. B. (2004), A Tale of two Countries' Conservatism, Service Quality, and Feedback on Customer Satisfaction. Journal of Service Research, 6 (3), 212-231.

Westbrook, R. A. (1987, August), Product/Consumption-Based Affective Responses and Postpurchase Processes. Journal of Marketing Research, 24, 258-270.

Westbrook, K. W. \& Peterson, R. M. (1998), Business-to-Business Selling Determinants of Quality. Industrial Marketing Management, 27 (1), 51-62. 
Winsted, K. F. (2000), Service Behaviors that Lead to Satisfied Customers. European Journal of Marketing, 34 (3/4), 399-417.

Witkowski, T.H. \& Wolfinbarger, M.F. (2002), Comparative Service Quality: German and American Ratings Across Service Settings. Journal of Business Research, 55 (11), 875881.

Yi, Y. (1990), A Critical Review of Consumer Satisfaction. In V. A. Zeithaml (Ed), Review of Marketing 1990. Chicago: American Marketing Association.

Zeithaml, V. A., Berry, L. L., \& Parasuraman, A. (1996, April), The Behavioral Consequences of Service Quality. Journal of Marketing, 60, 31-46.

Zeithaml, V.A. \& Bitner, M.J. (2003), Services Marketing: Integrating Customer Focus Across The Firm. New York: McGraw-Hill. 
Table 1: CFA Fit Measures

\begin{tabular}{|c|c|c|c|c|c|c|}
\hline Model & $\chi^{2}$ (d.f.) & $\Delta \chi^{2}(\Delta$ d.f. $)$ & RMSEA & GFI & NNFI & CFI \\
\hline $\mathrm{CFA}$ & $453.58(308)^{*}$ & na & .042 & .88 & .96 & .96 \\
\hline Model & $525.35(311)^{*}$ & $71.77(3)^{* *}$ & .046 & .87 & .94 & .95 \\
\hline $\begin{array}{l}\text { CFA = C } \\
\text { Model = } \\
\text { RMSEA } \\
\text { GFI = G } \\
\text { NNFI = } \\
\text { CFI = C } \\
* \text { Not si }\end{array}$ & $\begin{array}{l}\text { atory Factor Ana } \\
\text { ve plus structural } \\
\text { Mean Square Er } \\
\text { of Fit Index. } \\
\text { ormed Fit Index. } \\
\text { tive Fit Index. } \\
\text { t; } * * \text { Significant }\end{array}$ & $\begin{array}{l}\text { S } \\
\text { of Approximat for } \mathrm{H} 1 \text { to } \\
\text { of }\end{array}$ & & & & \\
\hline
\end{tabular}


Table 2: Coefficient Alpha, Composite Reliabilities and Average Variance Extracted

\begin{tabular}{|c|c|c|c|c|c|c|}
\hline Scale & $\begin{array}{l}\text { Number of } \\
\text { Items }\end{array}$ & Means & $\begin{array}{c}\text { Standard } \\
\text { Deviations }\end{array}$ & $\begin{array}{c}\text { Coefficient } \\
\text { Alpha }\end{array}$ & $\begin{array}{l}\text { Composite } \\
\text { Reliability }\end{array}$ & $\begin{array}{l}\text { Average } \\
\text { Variance } \\
\text { Extracted }\end{array}$ \\
\hline Service Encounter Quality Dimensions & & 6.74 & 1.41 & & & \\
\hline Professionalism & 2 & 6.83 & 1.61 & .89 & $\mathrm{n} / \mathrm{a}$ & $\mathrm{n} / \mathrm{a}$ \\
\hline Civility & 2 & 7.19 & 1.38 & .85 & $\mathrm{n} / \mathrm{a}$ & $\mathrm{n} / \mathrm{a}$ \\
\hline Friendliness & 2 & 5.95 & 1.91 & .81 & $\mathrm{n} / \mathrm{a}$ & $\mathrm{n} / \mathrm{a}$ \\
\hline Competence & 2 & 7.00 & 1.64 & .81 & $\mathrm{n} / \mathrm{a}$ & $\mathrm{n} / \mathrm{a}$ \\
\hline Service Quality Scales* & & 5.49 & .78 & & & \\
\hline Tangibles & 2 & 4.73 & .92 & .81 & $\mathrm{n} / \mathrm{a}$ & $\mathrm{n} / \mathrm{a}$ \\
\hline Reliability & 3 & 5.68 & 1.00 & & .92 & .71 \\
\hline Assurance & 2 & 5.86 & 1.12 & .78 & $\mathrm{n} / \mathrm{a}$ & $\mathrm{n} / \mathrm{a}$ \\
\hline Empathy & 2 & 5.66 & 1.20 & .73 & $\mathrm{n} / \mathrm{a}$ & $\mathrm{n} / \mathrm{a}$ \\
\hline Customer Satisfaction & 3 & 5.98 & 1.03 & & .85 & .66 \\
\hline Loyalty to the Organization & 4 & 4.48 & 1.20 & & .87 & .72 \\
\hline Loyalty to the Employee & 3 & 4.64 & 1.11 & & .76 & .60 \\
\hline
\end{tabular}

* Measured on a 9-point scale 
Figure 1: Conceptual Model

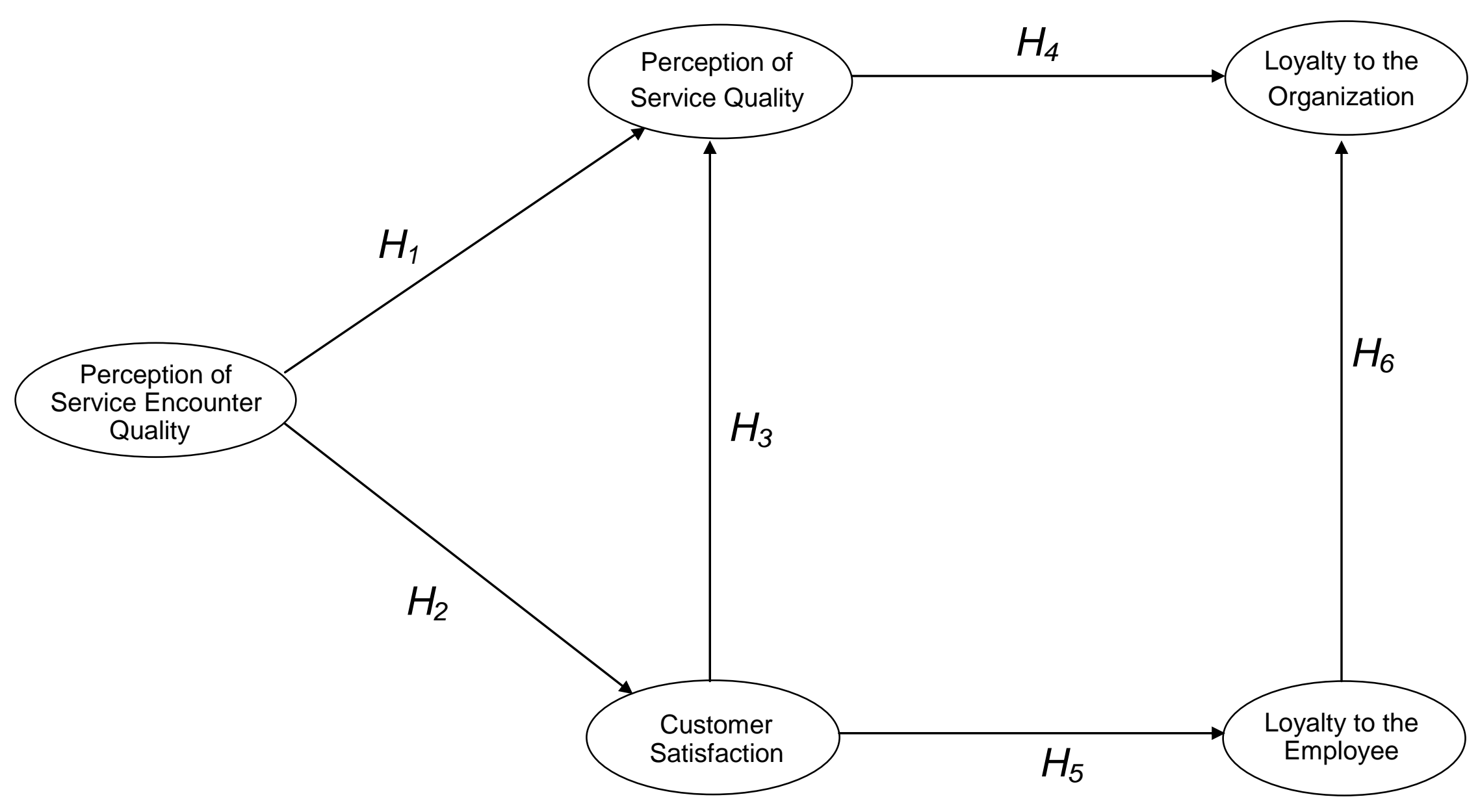


Figure 2: Structural Model

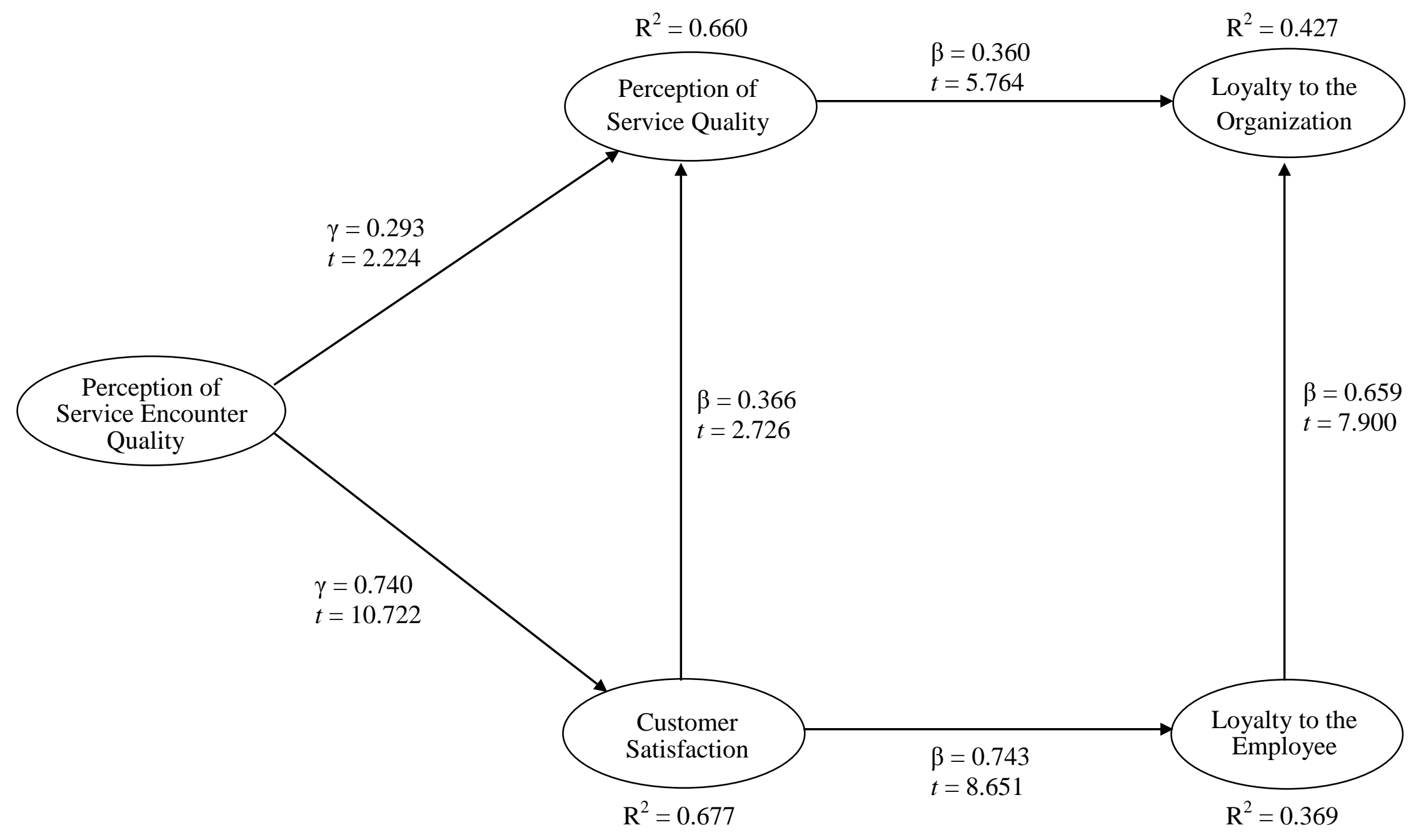




\section{APPENDIX A: A COMPARISON OF EARLY AND LATE RESPONDENTS}

The sample was split so that two groups of roughly equal sizes (both $20 \%$ of the total sample) were derived. The first group comprised the respondents who replied the earliest, and the second group was made up of the respondents who replied the latest. The t-tests compare the means of both groups for the 5 scales used in the study. Subsequent to a Levene test for equality of variances, the latter was not assumed.

\begin{tabular}{|c|c|c|c|c|c|c|c|c|}
\hline Scale & Groups & $\mathrm{N}$ & Mean & Std. dev & $\Delta$ mean & $\mathrm{t}$ & $\mathrm{df}$ & Sig \\
\hline \multirow{2}{*}{ SQ } & $\mathrm{E}$ & 56 & -10.839 & 15.686 & \multirow{2}{*}{-.639} & \multirow{2}{*}{-.226} & \multirow{2}{*}{103.795} & \multirow{2}{*}{.821} \\
\hline & $\mathrm{L}$ & 50 & -10.200 & 13.380 & & & & \\
\hline \multirow{2}{*}{ SEQ } & $E$ & 61 & -13.098 & 42.356 & \multirow{2}{*}{3.985} & \multirow{2}{*}{.513} & \multirow{2}{*}{104.658} & \multirow{2}{*}{.609} \\
\hline & $\mathrm{L}$ & 48 & -17.083 & 38.601 & & & & \\
\hline \multirow{2}{*}{ SAT } & E & 61 & 47.033 & 9.092 & \multirow{2}{*}{1.706} & \multirow{2}{*}{1.070} & \multirow{2}{*}{107.785} & \multirow{2}{*}{287} \\
\hline & $\mathrm{L}$ & 49 & 45.327 & 7.622 & & & & \\
\hline \multirow{2}{*}{ CLO } & $E$ & 59 & 63.593 & 15.385 & \multirow{2}{*}{4.873} & \multirow{2}{*}{1.760} & \multirow{2}{*}{106.852} & \multirow{2}{*}{.081} \\
\hline & $\mathrm{L}$ & 50 & 58.720 & 13.512 & & & & \\
\hline \multirow{2}{*}{ ILO } & E & 56 & 63.268 & 14.483 & \multirow{2}{*}{4.205} & \multirow{2}{*}{1.402} & \multirow{2}{*}{96.164} & \multirow{2}{*}{.164} \\
\hline & $\mathrm{L}$ & 48 & 59.063 & 15.874 & & & & \\
\hline
\end{tabular}

Key:

SQ: service quality

SEQ: service encounter quality

SAT: customer satisfaction

CLO: loyalty to the organization

ILO: loyalty to the individual

E: early respondent group

L: late respondent group

$\mathrm{N}$ : sample size

Std dev: standard deviation

df: degree of freedom

Sig: significance 


\section{APPENDIX B: SCALE INFORMATION WITH COMPLETELY STANDARDIZED LOADINGS (LAMBDA-X)}

\section{Service Encounter Quality Perceptions}

During your most recent service encounter with a XYZ contact person, you found them to...

Professionalism:

- Focus on not being pushy (SEQ06, .874)

- Focus on not being condescending in their communication(SEQ21, .918)

Civility:

- Be coherent in their communication (SEQ17, .837)

- Be courteous (SEQ37, .886)

Friendliness:

- Show familiarity to you during the service encounter (SEQ34, .918)

- Build a friendly relationship with you (SEQ35, .745)

Competence:

- Be informative in their interaction (SEQ01, .938)

- Be in possession of the necessary qualifications for conducting the required service (SEQ26, .765)

Service Quality Perceptions (Items adopted from Parasuraman, Zeithaml, and Berry, 1988)

Tangibles:

- XYZ's physical facilities are visually appealing (SQ02, .799)

- The appearance of the physical facilities of XYZ is in keeping with the type of services provided (SQ04, .886)

Reliability:

- When XYZ promises to do something by a certain time, it does so (SQ06, .971)

- When you have problems, XYZ is sympathetic and reassuring (SQ07, .852)

- $\quad \mathrm{XYZ}$ is dependable (SQ05, .862)

Assurance:

- You can trust employees of XYZ (SQ14, .767)

- Employees of XYZ are polite (SQ16, .867)

Empathy:

- Employees of XYZ do not give you personal attention (SQ19, .807)

- Employees of XYZ do not know what your needs are (SQ20, .757) 
Customer Satisfaction (Items adopted from Oliver, 1997)

I am satisfied with XYZ's...

- Level of knowledge of the product(s) serviced (CS06, .798)

- Contact person's commitment to providing a high level of service (CS07, .868)

- Information provided by the contact person on product usage (CS08, .752)

Firm Loyalty (Items adopted from Mowday, Steers and Porter, 1979)

- I am willing to put in extra effort to receive services from XYZ (CLO01, .784)

- I am proud to tell others that I purchase service provision from XYZ (CLO06, .853)

- $\quad$ XYZ stimulates me to buy from XYZ repeatedly (CLO08, .771)

- For me, XYZ is the best possible organization to buy service provision from (CLO14, .771)

Individual Loyalty (Items adopted from Mowday, Steers and Porter, 1979)

- My values and the values of my current contact person are very similar (ILO05, .706)

- I am extremely glad that I chose my current contact person over other (ILO10, .649)

- I really care about the fate of my current contact person (ILO12, .780) 


\section{APPENDIX C: CORRELATION AND COVARIANCE MATRICES}

Key:

SQ : $\quad$ service quality

SEQ : service encounter quality

CUS_SAT : customer satisfaction

LOY_ORG : loyalty to the organization

LOY_IND : loyalty to the individual

All correlations in the tables below are significant at .000 .

CORRELATIONS OF SCALES:

\begin{tabular}{l|cccc} 
SEQ & .671 & & & \\
CUS_SAT & .660 & .710 & .613 & \\
LOY_ORG & .634 & .586 & .563 & .701 \\
LOY_IND & .564 & .588 & CUS_SAT & LOY_ORG
\end{tabular}




\section{APPENDIX C: CORRELATION AND COVARIANCE MATRICES (CONTINUED)}

COVARIANCES OF SCALES:

\begin{tabular}{|c|c|c|c|c|c|}
\hline SQ & .611 & & & & \\
\hline SEQ & .739 & 1.984 & & & \\
\hline CUS_SAT & .529 & 1.025 & 1.051 & & \\
\hline LOY_ORG & .595 & .990 & .754 & 1.440 & \\
\hline LOY_IND & .490 & .920 & .641 & .934 & 1.233 \\
\hline & SQ & SEQ & CUS_SAT & LOY_ORG & LOY_IND \\
\hline
\end{tabular}




\section{APPENDIX C: CORRELATION AND COVARIANCE MATRICES (CONTINUED) CORRELATIONS OF ITEMS:}

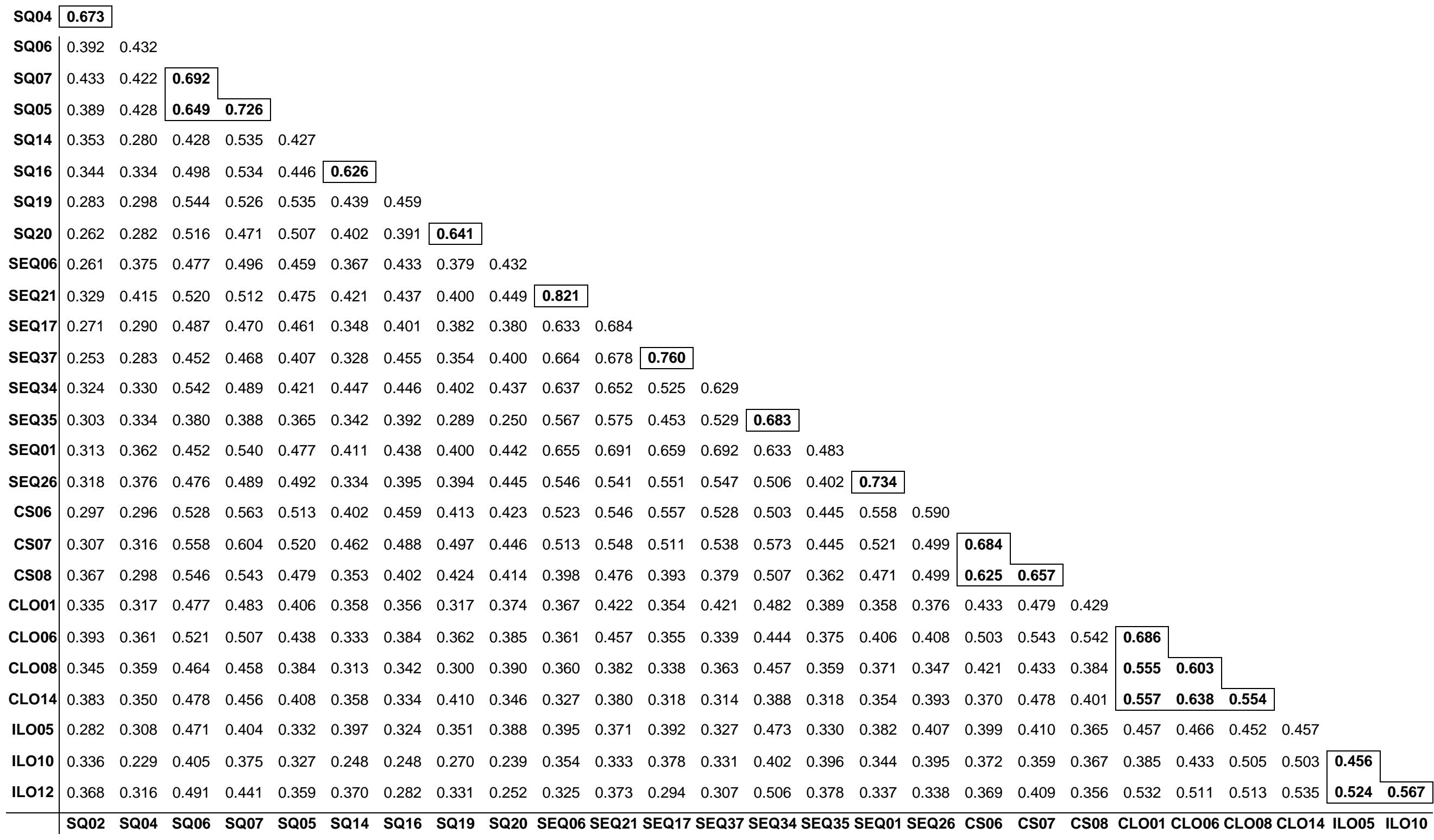


